\title{
ДОСВІД ЛІКУВАННЯ ГОСТРОГО ДЕСТРУКТИВНОГО ПАНКРЕАТИТУ
}

\author{
ДВНЗ «Тернопільський державний медичний університет ім. І.Я. Горбачевського МОЗ України»
}

Тернопільська міська комунальна лікарня швидкої допомоги

Резюме. У статті подано досвід лікування хворих із гострим деструктивним панкреатитом у Тернопільській міській комунальній лікарні швидкої допомоги за останні три роки. Проаналізовано результати лікування 84 хворих із тяжким перебігом захворювання. Встановлено зниження за останні роки кількості хворих на гострий панкреатит, хоча частка деструктивних форм та смертність залишаються стабільними. Відпрацьована у відділенні тактика лікування гострого панкреатиту дала

Вступ. Гострий панкреатит на сьогодні $€$ одним із найпоширеніших і найважчих із хірургічних захворювань $[1,3,11,12]$. Діагностика його $\epsilon$ однією із тяжких проблем хірургії, а клінічний перебіг, розвиток ускладнень та кінцевий результат лікування є часто непередбачуваним.

За останні 50 років захворюваність на гострий панкреатит у світі зросла приблизно в 10 разів $[3,8]$. Захворюваність на гострий панкреатит в Україні має неухильну тенденцію до зростання, сягаючи в деяких регіонах 12,4 на 10000 осіб на рік [5]. У світі даний показник в середньому коливається від 5 до 80 випадків захворювання на 100000 чоловік в рік $[9,11,12]$. За захворюваністю дана патологія в Україні вийшло за останнє десятиріччя на друге місце серед гострих захворювань органів черевної порожнини після гострого апендициту, а в багатьох регіонах Росії та Білорусі посідає перше місце [1-3, 5]. Високий рівень захворюваності в нашій країні пов'язаний передусім із зростанням вживання алкоголю, незбалансованим харчуванням, екологічними проблемами та покращенням діагностики даного захворювання. Загальна летальність при гострому панкреатиті коливається від 4,5 до $15 \%$ (по Україні, в середньому, 14,1-14,66 \%, у Росії - 22$25 \%$, у США - 16,7 \%, у Німеччині - 5,8 \%, у Чехії - $2 \%$ ). При деструктивних формах вона становить 24-60 \%, а післяопераційна досягає 70 \% і не має тенденції до зниження, незважаючи на розробку та впровадження нових методів лікування $[2,3,5,10,13]$. Досягненням останніх десятиріч $є$ зниження рівня ранньої смертності від даного захворювання, що пов'язано з удосконаленням алгоритму консервативного лікування, хоча смертність від гострого панкреатиту в період розвитку пізніх ускладнень (зокрема гнійних) залишається високою $[1,5,11]$. У 73 \% після перенесеного гострого панкреатиту виникає стійка втрата працездатності, що надає проблемі соціальної значущості, оскільки пік захворюваності припадає на осіб працездатного віку - 30-50 років $[3,12]$. Вражають також і економічні витрати на лікування гострого панкреатиту. Так, у США можливість знизити відсоток гнійно-септичних та тромбоемболічних ускладнень, зменшити тривалість перебування хворих у стаціонарі та утримувати летальність від гострого деструктивного панкреатиту на низькому рівні. Розроблені чіткі покази до оперативного лікування із переважанням малоінвазивних технологій.

Ключові слова: гострий деструктивний панкреатит, діагностика та лікування захворювання, малоінвазивні методи хірургічного лікування.

щороку витрачається на лікування осіб із цим захворюванням близько 2 млрд доларів, у Канаді - більш як 200 млн доларів [9, 12]. Лікування пацієнта із гострим панкреатитом $є$ одним із найбільш вартісним порівняно 3 витратами на лікування інших хірургічних захворювань.

На сьогодні залишається не до кінця визначеним питання оптимального вибору тактики лікування хворих на гострий деструктивний панкреатит. На жаль, лікування некротичного гострого панкреатиту $є$ неспецифічним і в більшості випадків застосовується лише підтримуюча терапія. Єдиних підходів у лікуванні захворювання до цих пір не існує, загальноприйнята тактика відсутня, не визначено раціонального співвідношення консервативних та хірургічних методів у загальному комплексі лікувальних заходів при цьому тяжкому захворюванні. Терапія гострого панкреатиту за останні десятиліття зазнала значних змін, хоча і була сповнена ланцюгом невиправданих надій i розчарувань у пошуках «ідеального засобу та алгоритму», і цей пошук продовжується і по сьогоднішній день $[1,7,8]$.

Мета дослідження. Визначити важливі тактичні та лікувальні аспекти, які б дозволили покращити результати лікування та запобігти розвитку ускладнень у хворих на гострий деструктивний панкреатит на основі досвіду клініки та сучасної літератури.

Матеріал і методи. За період з 2013 по 2015pp. у хірургічному відділені Тернопільської міської комунальної лікарні швидкої допомоги проліковано 546 хворих на гострий панкреатит. У структурі гострої абдомінальної патології це захворювання посідає у клініці 3-тє місце, поступаючись гострому апендициту та холециститу. При цьому відмічається тенденція до зниження кількості хворих на гострий панкреатит. У середньому частка деструктивних форм захворювання становить $15,4 \%$ (84 хворих). У 2013 році ця частка становила $14,7 \%$, у 2014 - 15,3\%, а у 2015 $16,5 \%$. Відсоток деструктивного панкреатиту залишається відносно стабільним, а тенденцію до зростання тяжких форм захворювання варто по- 
яснити зниженням кількості хворих із легким панкреатитом та із зменшенням гіпердіагностики захворювання. Серед 84 хворих на деструктивний панкреатит чоловіків було 58 (69 \%), жінок 26 (31\%). Середній вік хворих склав 47,1 $\pm 11,9$ року (чоловіків - 43,6 $\pm 10,9$ року, жінок $54,8 \pm 10,6$ року). За етіологічним чинником переважала роль біліарного фактора (рис. 1).

Під біліарним етіологічним фактором ми розуміємо як біліарний панкреатит, так і наявні у пацієнта захворювання жовчовивідних шляхів, які могли спровокувати розвиток гострого панкреатиту (частка біліарного панкреатиту становить $24 \%$ ). Алкогольно-аліментарний чинник становить 57 \%. При цьому в чоловіків превалює панкреатит алкогольної етіології, а у жінок - біліарної.

Усім особам при госпіталізації в клініку проводили стандартні обстеження згідно з протоколами надання медичної допомоги [5]: клінічне обстеження пацієнта, загальноклінічні аналізи крові i сечі, глюкози крові, визначення групи крові за системою AB0 та Rh-фактору; біохімічні дослідження крові із визначенням рівня білірубіну і його фракцій, активності трансфераз і альфаамілази сироватки крові, сечовини, креатиніну сироватки крові, електролітів крові, загального білка крові, діастази сечі, коагулограми.

Із апаратних методів дослідження застосовували ультразвукове дослідження органів черевної порожнини та плевральних синусів, ендоскопічну фіброгастродуоденоскопію (ЕФГДС), оглядову рентгенографію черевної порожнини і грудної клітки, комп'ютерну томографію (КТ), лазерну допплерівську флоуметрію (за показаннями).

Усі хворі із тяжким панкреатитом 3 приймального відділення госпіталізуються у відділення анестезіології та інтенсивної терапії. Тактика лікування пацієнтів подана у вигляді алгоритму (рис. 2)

Оцінка тяжкості стану хворого та прогнозування перебігу захворювання проводилось за допомогою шкали BISAP та запропонованого в нашій клініці способу [6].

Значну увагу приділяємо тривалості захворювання до етапу госпіталізації в стаціонар. Особливу увагу заслуговують пацієнти, тривалість клінічних проявів панкреатиту в яких не перевищує 24 години. Частка таких пацієнтів становить $30 \%$. Як відомо, тяжкість гострого панкреатиту i подальший перебіг захворювання багато в чому визначається в першу добу від його початку, до повного формування первинного деструктивного вогнища. Динамічність початкового періоду розвитку гострого панкреатиту припускає можливість не тільки прогресування, але й регресування панкреанекрозу.

Основою ранньої терапії гострого панкреатиту $€$ запобігання прогресуванню запалення в підшлунковій залозі та системної запальної відповіді шляхом переривання однієї з ключових ланок в їх патогенезі. При ранньому підключенні інтенсивного комплексу лікування досягається «обриваючий» лікувальний ефект, за якого відбувається купірування або різке обмеження деструктивного процесу в підшлунковій залозі та ефективна профілактика гнійних ускладнень гострого панкреатиту [1]

Лікування деструктивного панкреатиту завжди розпочиналося з інтенсивної консервативної терапії і иї ефективність є однією з основних показів до оперативного лікування. До комплексу консервативної терапії входили:

Декомпресія шлунка, місцева гіпотермія;

- Корекція дегідратації (інфузійна терапія);

- Знеболення та спазмолітична терапія;

- Пригнічення секреції шлунка (блокатори протонної помпи);

- Антимікробна терапія (карбопенеми, цефалоспорини IV покоління + орнідазол);

- Стимуляція діурезу;

- Профілактика тромбоемболічних ускладнень (низькомолекулярні гепарини в профілактичних дозах);

- Стимуляція перистальтики (метоклопрамід, очисна клізма, препарати калію, сорбілакт, раннє ентеральне харчування);

- Корекція порушень мікроциркуляції (пентоксифілін, корвітин, реосорбілакт);

- Корекція гіпопротеїнемії (альбумін, амінокислоти за потреби);

- Інтенсивна посиндромна терапія спрямована на корекцію роботи серцево-судинної системи

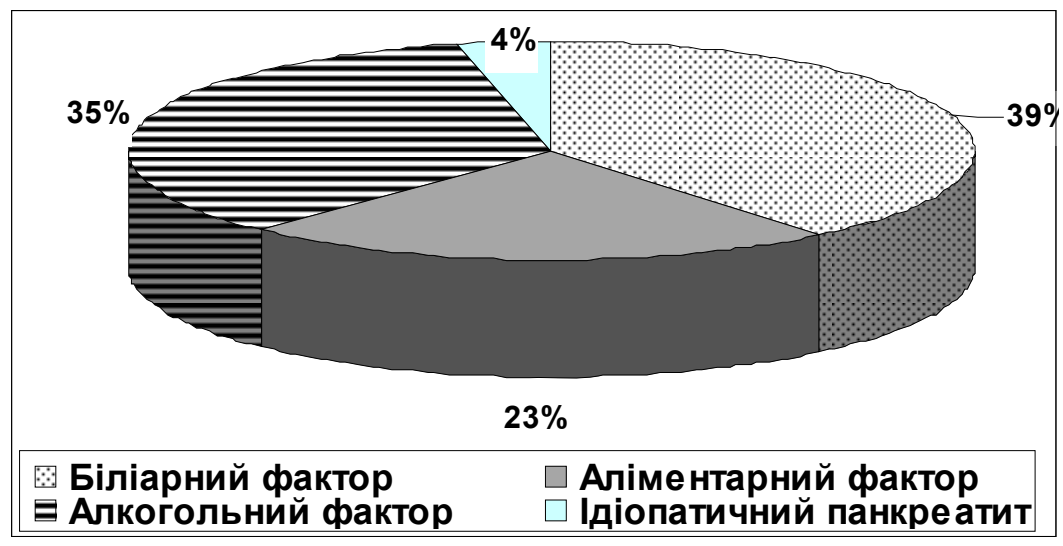

Рис. 1. Етіологічна структура гострого панкреатиту в обстежених хворих 


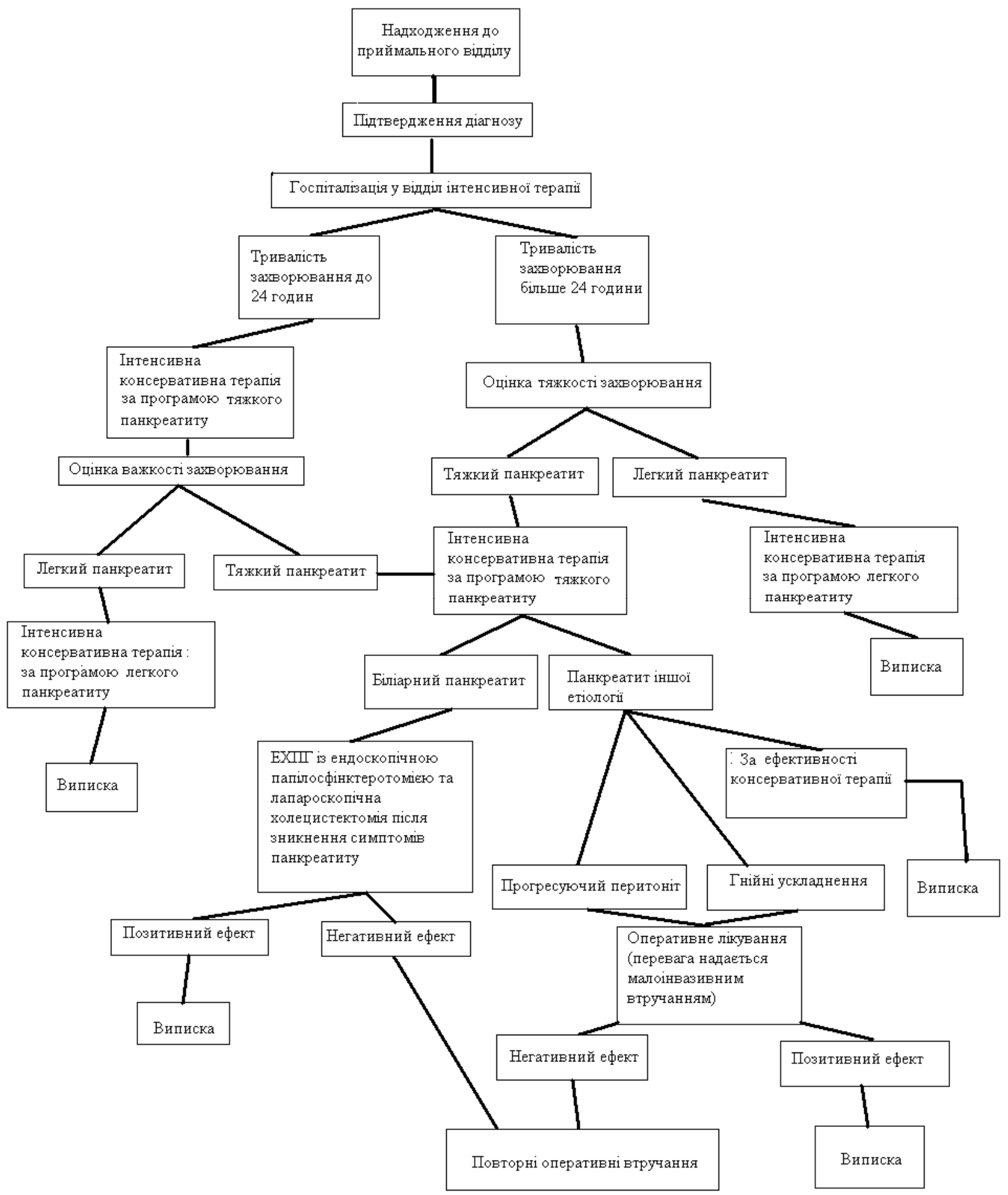

Рис. 2. Тактичний алгоритм лікування хворих на гострий панкреатит

(за нестабільної гемодинаміки), респіраторна підтримка та ін.).

Ефективність використання препаратів соматостатину в нашій клініці є сумнівною. Використання інгібіторів протеаз ефективне лише в перші три доби захворювання.

Досвід клініки показав, що хірургічне лікування деструктивного панкреатиту показане при:

- біліарному панкреатиті з наростаючою жовтяницею або ж із деструкцією жовчного міхура;

- панкреатогенному перитоніті за неефективності консервативної терапії;

- гнійних ускладненнях гострого панкреатиту;
- неможливості виключити гостру хірургічну патологію інших органів черевної порожнини, що вимагає екстреного втручання.

У випадку ствердження біліарного панкреатиту, після комплексу спазмолітичної, антисекреторної, протизапальної терапії, тривалістю близько двох годин, проводили ендолюмінальні оперативні втручання за умови відсутності протипоказань, зокрема пенкреатогенного шоку та стандартних протипоказів до ендоскопії.

Алгоритм втручання передбачав: дуоденоскопію, канюлізацію великого дуоденального сосочка, введення провідника, аспіраційну пробу. При ствердженні наявності інструментів у поза- 


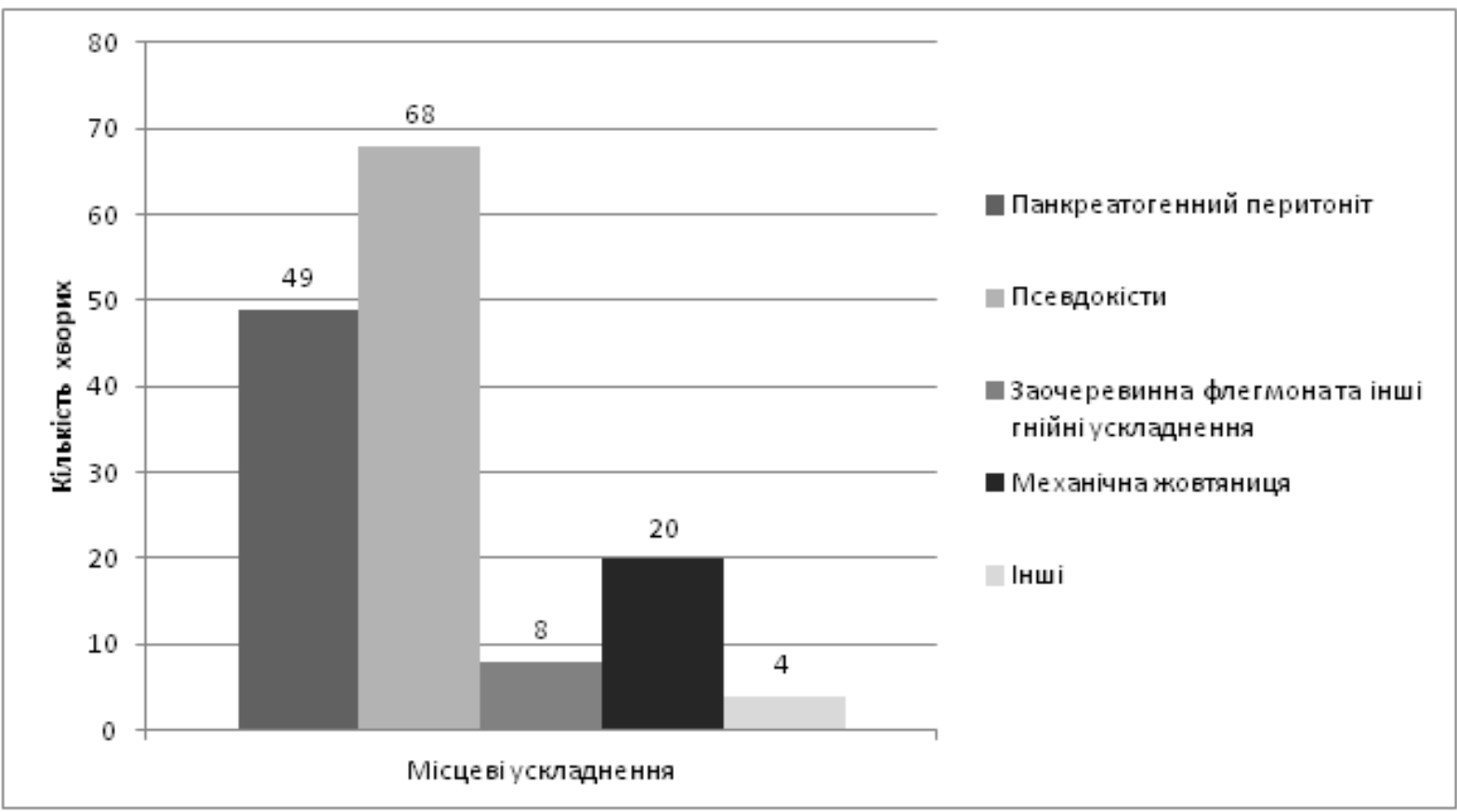

Рис. 3. Структура місцевих ускладнень гострого панкреатиту в обстежених хворих

печінкових жовчних протоках, проводили папілотомію з балонною літоекстракцією. У випадку транслокації конкремента в дванадцятипалу кишку (ДПК) та виділення жовчі під тиском оперативне втручання завершували без ендоскопічної холангіопанкреатографії (ЕХПГ).

Оперативні втручання в період гемодинамічних порушень та панкреатогенного шоку (перші три-чотири доби перебігу захворювання) не проводяться.

Для оцінки ефективності лікування нами оцінювалися тривалість перебування хворих у стаціонарі, характер ускладнень, потреба в хірургічному втручанні та смертність.

Результати досліджень та їх обговорення. 384 госпіталізованих хворих, 25 госпіталізовані в перші 24 години від початку захворювання, у період гемодинамічних порушень (від 24 годин до 4 днів) госпіталізовано 31 хворого, 16 хворих - у період недостатності паренхіматозних органів, 4 хворих - із гнійними ускладненнями. Лікування усіх хворих на гострий деструктивний панкреатит починалось із консервативної терапії у відділені анестезіології та інтенсивної терапії. Ефективність іiі використання без оперативного втручання відмічено у 18 (21\%) пацієнтів. Прооперовано 66 (79\%) пацієнтів із деструктивним панкреатитом. У 36 (54 \%) випадках проводилася лапароскопія із дренуванням сальникової сумки та черевної порожнини, у 13 (20 \%) - дренування сальникової сумки та черевної порожнини з лапаротомного доступу, в 11 (17\%) випадках - лапаротомія, холецистектомія із зовнішнім дренуванням спільної жовчної протоки. У 6 випадках проводилась ЕХПГ з ендоскопічною папілосфінктеротомією. 3 (4 \%) оперативні втручання виконано при надходженні у стаціонар у пацієнтів із гнійними ускладненями (розкриття та дренування гнійників). У 8 (12\%) осіб проводилися повторні оперативні втручання.

Показами до оперативних втручань у ранні терміни були: прогресуючий панкреатогенний перитоніт - 74 \%; біліарний панкреатит - $17 \%$. У пізні терміни захворювання оперативні втручання виконувалися при гнійних ускладненнях (12\% випадків) (з них у 5 осіб, як повторні оперативні втручання). В одному випадку проводилось оперативне втручання у зв'язку 3 арозивною кровотечею із підшлункової залози.

Структура ускладнень гострого деструктивного панкреатиту подана на діаграмі (рис. 3).

Серед системних ускладнень поліорганна недостатність встановлена у $24 \%$ осіб, плеврит у $68 \%$ випадків, респіраторний дистрес-синдром - у $3 \%$ випадків, шок - $21 \%$, гіпокальційемія $42 \%$, гіперглікемія - $39 \%$, гіпопротеїнемія $51 \%$, тромбоемболічні ускладнення - у $17 \%$ випадків.

За 2015 р. відмічається зниження розвитку гнійно-септичних (на 40\% порівняно із 2013 р. та на $25 \%$ порівняно із 2015 р.) та тромбоемболічних ускладнень (на 34 \% порівняно із 2013 р.).

Ефективність лікування багато в чому залежала від терміну госпіталізації. Так, при госпіталізації в перші 24 години необхідність в оперативних втручаннях знижувалась до $52 \%$, відсоток гнійних ускладнень знижувався до $8 \%$, значно знижувався відсоток тромбоемболічних ускладнень (4 \%) та поліорганної недостатності (12\%). Середній термін перебування осіб із деструктивним панкреатитом у стаціонарі становив 12,2 $\pm 4,5$ ліжко-дня (у 2013 р. - 14,3 $\pm 5,8$ ліжко-дня, у 2014

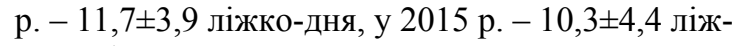
ко-дня).

Померло 12 хворих на гострий деструктивний панкреатит (4 особи у 2013 р., 5 осіб у 2014 
p. та 3 особи за 9 місяців 2015 р.). 3 них прооперовано 9 осіб. Причина смерті у трьох пацієнтів тромбоемболія легеневої артерії, у семи пацієнтів - поліорганна недостатність, у двох пацієнтів шок, зокрема в одного пацієнта панкреатогенний шок при блискавичному перебігу захворювання, та в одного - ендотоксичний шок при розриві нагноєної кісти підшлункової залози. У чотирьох осіб діагностовано біліарний панкреатит, у семи - алкогольний, в одного - аліментарний. У 2013 році у $50 \%$ хворих діагностовано біліарний панкреатит, у 2014 р. - у $20 \%$, у 2015 р. - у $33 \%$ випадків. Середній термін перебування пацієнтів, які померли в стаціонарі внаслідок гострого панкреатиту у 2013 р. становив $13,2 \pm 6,7$ ліжко-дня, у

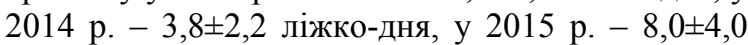
ліжко-дня. Смертність від гострого деструктивного панкреатиту у 2013 р. становила $12,5 \%$, у 2014 p. $-17,2 \%$, y 2015 p. $-13 \%$.

\section{Висновки}

1. У нашій клініці за останні три роки відмічається зниження кількості хворих на гострий панкреатит, хоча частка деструктивних форм та смертність залишаються стабільними.

2. Відпрацьована у відділенні тактика лікування гострого панкреатиту дала можливість знизити відсоток гнійно-септичних та тромбоемболічних ускладнень, зменшити тривалість перебування хворих у стаціонарі та утримувати летальність від гострого деструктивного панкреатиту на низькому рівні.

3. Лікування хворих на біліарний панкреатит iз використанням малоінвазивних оперативних технологій дозволив знизити відсоток смертності від цієї патології.

4. Найкращі результати лікування відмічались у пацієнтів, тривалість захворювання яких до надходження в стаціонар не перевищувала 24 години.

Перспективи подальших досліджень. У подальшому планується удосконалення методів надання медичної допомоги особам із гострим панкреатитом, впровадження в практику та розробка нових методів діагностики та лікування деструктивного панкреатиту. Особливої уваги заслуговує розробка лікувальних заходів на ран- ніх термінах розвитку патології для профілактики розвитку тяжких форм панкреатиту та формування ускладнень.

\section{Література}

1. Острый панкреатит (Протоколы диагностики и лечения) / С.Ф. Багненко, А.Д. Толстой, В.Б. Красногоров [и др.] // Анналы хирург. гепатол. - 2006. - Т. 11, № 1. - C. 60-66.

2. Коновалов Е.П. Этиология и патогенез острого панкреатита (Обзор литературы) / Е.П. Коновалов // Анналы хирург. гепатол. - 2000. - Т. 5, № 2. - С. 48-53.

3. Мальцева Л.А. Острые панкреатиты: эпидемиология, патогенез, диагностика, организация лечения, интенсивная терапия / Л.А. Мальцева, Л.В. Усенко, Люлько И.В. [и др.] - К.: Четверта хвиля, 2005. - 256 с.

4. Профилактика гнойных осложнений острого деструктивного панкреатита: учебное пособие для врачей [под. ред. С.Ф. Багненко]/ Санкт-Петербургский государственный НИИ скорой помощи им. проф. И.И Джанелидзе. - СПб., 2002. - 23 с.

5. Стандарти надання медичної допомоги хворим 3 невідкладними хірургічними захворюваннями органів черевної порожнини: Наказ МО3 України № 297 від 02.04.2010 [Электронный ресурс] - Режим доступу: http://www.surgery 2 fipo.dsmu.edu.ua/

6. Чорномидз А.В. Прогнозування перебігу гострого панкреатиту на ранніх стадіях розвитку захворювання / А.В. Чорномидз // Укр. наук.-мед. молод. ж. 2013. - Спец. вип. - № 2. - С. 12-13.

7. Хомерики Н.М. Патогенетически обоснованные подходы к лечению панкреатитов / Н.М. Хомерики, С.Г. Хомерики // Фарматека. - 2007. - № 13 (147). C. 74-78.

8. Шотт А. В. Эволюция методов лечения острого панкреатита / А.В. Шотт, С.И. Леонович, Г.Г. Кондратенко // Здравоохранение. - 2006. - № 12. - С. 40-46.

9. Guidelines for the management of acute pancreatitis. Working Party report / J. Toouli, M. Brook-Smith, C. Bassi [et al.] // J. Gastroenterology and Hepatology. - 2002. № 17. - P. 15-39.

10. Mortality in patients with acute pancreatitis / A. Taj, M.T. Ghafoor, W. Amer [et al.] // PAK J. gastroenterol. 2002. - Vol. 16 (2). - P. 35-38.

11. Sanchez A.C. Acute pancreatitis / A.C. Sanchez, J.A.G. Aranda // Bol. Med. Hosp. Infant Mex. - 2012. № 69 (1). - P. 3-9.

12. Takeda K. JPN Guidelines for the management of acute pancreatitis: medical management of acute pancreatitis / K. Takeda, T. Takada, Y. Kawarada // J. Hepatobiliary Pancreat Surg. - 2006. - № 13(1). - P. 42-47.

13. The early prediction of mortality in acute pancreatitis: a large population-based study / B.U. Wu, R.S. Johannes, X. Sun [et al.] // Gut. - 2008. - Vol. 57. - P. 1698-1703.

\section{ОПЫТ ЛЕЧЕНИЯ ОСТРОГО ДЕСТРУКТИВНОГО ПАНКРЕАТИТА}

\section{Д.В. Осадчук, А.В. Чорномидз}

Резюме. В статье представлен опыт лечения больных с острым деструктивным панкреатитом в Тернопольской городской коммунальной больнице скорой помощи за последние три года. Проанализированы результаты лечения 84 больных с тяжелым течением заболевания. Установлено снижение за последние годы количества больных острым панкреатитом, хотя доля деструктивных форм и смертность остаются стабильными. Отработанная в отделении тактика лечения острого панкреатита позволила снизить процент гнойно-септических и тромбоэмболических осложнений, уменьшить длительность пребывания больных в стационаре и удерживать летальность от острого деструктивного панкреатита на низком уровне. Разработаны четкие показания к оперативному лечению с преобладанием малоинвазивных технологий.

Ключевые слова: острый деструктивный панкреатит, диагностика и лечение заболевания, малоинвазивные методы хирургического лечения. 


\section{EXPERIENCE OF TREATING ACUTE DESTRUCTIVE PANCREATITIS}

\section{D.V. Osadchuk, A.V. Chornomydz}

Abstract. The article describes the experience of the treatment of patients with acute destructive pancreatitis in Ternopil municipal emergency hospital for the last 3 years. Results of treatment of 84 patients with severe disease have been analyzed. There has been a decrease in the number of patients with acute pancreatitis in recent years, although the proportion of destructive forms and mortality has remained stable. The tactics of treatment of acute pancreatitis which had been developed in the department has reduced the percentage of septic and thromboembolic complications, reduced the duration of hospital stay and kept the mortality of acute destructive pancreatitis at a low level. Clear indications for surgical treatment with a predominance of minimally invasive technologies were developed.

Key words: acute destructive pancreatitis, diagnosis and treatment of disease, minimally invasive surgical techniques.

HSEI "I.Y. Horbachevskyi State Medical University of MHP of Ukraine” (Ternopil) Municipal Emergency Hospital (Ternopil)

Рецензент - проф. В.П. Польовий

Buk. Med. Herald. - 2016. - Vol. 20, № 2 (78). - P. 235-240

Надійшла до редакції 21.02.2016 року

(ㄱ Д.В. Осадчук, А.В. Чорномидз, 2016 